\title{
POTAMOGETON PUSILLUS AGG. IN TAJIKISTAN (MIDDLE ASIA)
}

\author{
MARCIN NOBIS $^{1 *}$, ARKADIUSZ NOWAK ${ }^{2}$, JOANNA ZALEWSKA-GAŁOSZ $^{1}$ \\ ${ }^{1}$ Department of Plant Taxonomy and Phytogeography, \\ Institute of Botany, Jagiellonian University \\ Kopernika 27, 31-501 Kraków, Poland \\ *e-mail:m.nobis@uj.edu.pl \\ ${ }^{2}$ Laboratory of Geobotany and Plant Conservation, \\ Department of Biosystematics, Opole University \\ Oleska 48, 45-022 Opole, Poland
}

(Received: December 29, 2009. Accepted: June 2, 2010)

\begin{abstract}
The locality of Potamogeton berchtoldii Fieber, the new species to the flora of Tajikistan (Middle Asia), together with its ecological conditions are presented. Additionally, the list of herbarium specimens of $P$. pusillus L. s. stricto gathered in Tajikistan and few specimens of $P$. berchtoldii collected from the area of adjacent countries are also provided. Taxonomical position of the species within the Potamogeton pusillus aggregation, the main morphological features of both taxa and possibility of finding other localities are discussed.
\end{abstract}

KEY WORDS: Potamogeton berchtoldii, P. pusillus aggregation, taxonomy, distribution, Tajikistan, Middle Asia.

\section{INTRODUCTION}

The knowledge of the genus Potamogeton L. in Tajikistan, concerning number of taxa occurring in the area of the country and their distribution is very scrappy and incomplete. The most essential source of floristic information on this genus is Flora of the Soviet Republic of Tajikistan (Sidorenko 1957), published more than half a century ago. A few, additional data were supplied by Zakirov (1961), Ikonnikov (1963, 1979), Vvedenskii (1968) and recently Nobis and Nowak (2008). Based on these papers, the pondweed flora of Tajikistan consists of nine species of Potamogeton: $P$. crispus L., $P$. friesii Rupr., $P$. gramineus L. (=P. heterophyllus Schreb.), P. lucens L., P. natans L., $P$. nodosus Poir., P. perfoliatus L., P. pusillus L. and P. tubulatus Hagstr. (Sidorenko 1957; Ikonnikov 1963, 1979). Four other pondweed taxa have been classified in the separate genus Stuckenia Börner. These are: S. amblyphylla (C. A. Mey.) Holub, S. filiformis (Pers.) Börner, S. pamirica (Baagöe) Z. Kaplan and S. pectinata (L.) Börner (Kaplan 2008). The majority of Potamogeton species are considered as the rarest elements of the Tajik Flora (known from only one location in a case of $P$. tubulatus or P. natans to maximum ca. thirty stations for $P$. perfoliatus). The lack of modern taxonomical and chorological synthesis of Potamogeton in Tajikistan impedes further and more detailed studies on its biogeography and conservation.

During authors' studies carried out in 2008 on the territory of Zeravshan Mts. (western part of Pamir Alai Mts) the new species to the flora of Tajikistan - Potamogeton berchtoldii Fieber was recorded. This finding was a prompt to the taxonomical revision of $P$. pusillus L. agg. based on herbaria materials from the area of Tajikistan. The aims of the present study are (1) to provide the information on location and ecological conditions of the new to Tajik's flora pondweed species, (2) to present the distribution of $P$. berchtoldii Fieber and $P$. pusillus L. s. stricto in Tajikistan based on investigated herbaria specimens and (3) to present the main morphological features of both taxa. The authors also want to highlight the problem of incompleteness of the chorological and taxonomical knowledge regarding Potamogeton and Stuckenia and stimulate further researches in Tajikistan and the whole area of Middle Asia.

\section{MATERIAL AND METHODS}

All specimens deposited in TAD belonging to Potamogeton pusillus agg. and gathered from the area of Tajikistan were reviewed. Additionally, specimens representing this group, collected from other Middle Asian countries (Kazakhstan, Uzbekistan, Turkmenistan and Kyrgyzstan) and deposited in TASH were examined. Localities of $P$. pusillus L. s. sticto from Tajikistan and all stations of $P$. berchtoldii revealed during the revision are provided in the distribution list. Each specimen of Potamogeton pusillus agg. was determined based on stipules examination: open and convolute $-P$. berchtoldii Fieber, close and connate - 


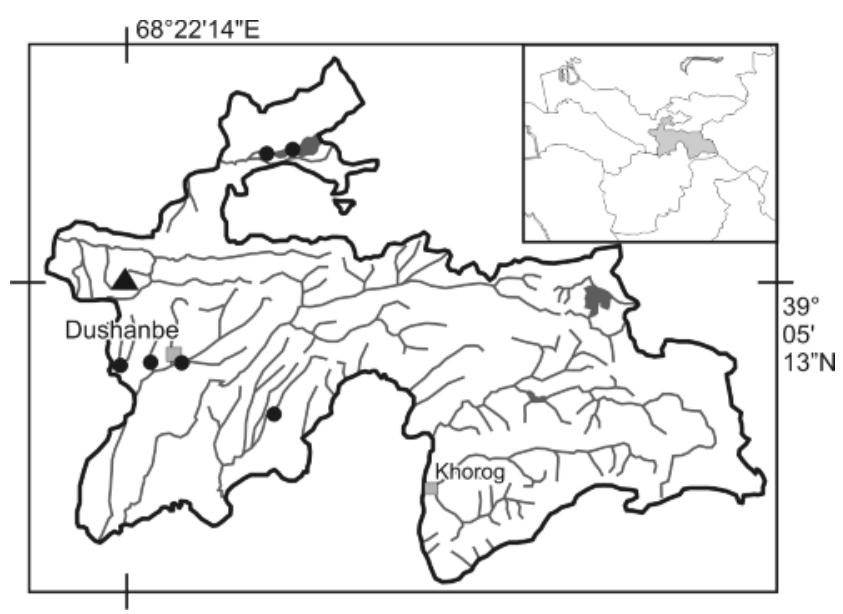

Fig. 1. Distribution map of Potamogeton pusillus L. agg. in Tajikistan; $\Delta$ - the new locality of $P$. berchtoldii Fieber; - a locality of $P$. pusillus L. s. stricto.

$P$. pusillus L. s. stricto. Specimens of $P$. berchtoldii from the new locality in Tajikistan were deposited in KRA and OPUN. Acronyms of Herbaria follow Holmgren et al. (1990). Water proprieties were measured for hydrogen ions with $\mathrm{pH}$ meter ELMETRON C-CP-104 and for concentration of diluted salt with conductivity-meter CC-411.

\section{RESULTS}

The newly discovered population of Potamogeton berchtoldii was found in a small section of the brook rising from the small alpine lake Serimadarun with an inlet in lake Iskanderkul' nearby the Varzob camp ground, western Ta-

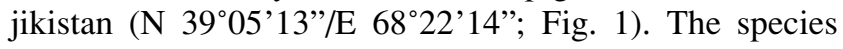
occurs in few scattered locations in slowly flowing $(0.4$ $\mathrm{m} / \mathrm{s}$ ), clear and transparent water (the depth from 0.8 to 1 $\mathrm{m})$. The brook's bottom was muddy with mineral and organic sediments. $P$. berchtoldii occurs within the section of $15 \mathrm{~m}$ with the average cover in vegetation patches ranging from 30 to $90 \%$. The $\mathrm{pH}$ reaction was $7.76-7.83$, water temperature in June $11.0-11.8^{\circ} \mathrm{C}$ and conductivity $190-260$ $\mu \mathrm{S} / \mathrm{cm}$.

Individuals of $P$. berchtoldii from Tajikistan represent robust, river morphotype. Plants are vegetative, sparingly branched, with well-developed nodal glands. Submerged leaves are sessile, linear, with mucronate apex, dark green, relatively wide, $\pm 2.0 \mathrm{~mm}$ and $\pm 55 \mathrm{~mm}$ long, with one to two lateral veins on each side of the midrib, marginal veins are absent. Midrib is bordered by two to four rows of lacunae, which reach the leaf apex. Stipules are open and convolute, on the average $13 \mathrm{~mm}$ long, hyaline with a gree- nish tingle. All morphological characters fit well to known variability of this species (compare Casper and Krausch 1980; Preston 1995; Zalewska-Gałosz 2008).

A list of $P$. berchtoldii specimens revealed during the study

1. Syr-Daria district (Uzbekistan) [Syr-Daryiska Oblast, Aule-Atinskii Uiezd, dolina reki?], 17.07.1922, leg.?, rev. A. Nowak (TASH).

2. Syr-Daria delta, Karashalan lake (Kazakhstan) [Delta Syr-Darii, zalev Kara-Shalandy], 11.07.1921, leg. I. L. Raikova, (mixed collection with S. filiformis), rev. A. Nowak (TASH).

3. Karashalandy lake (Kazakhstan) [Zalev Kara-Shalandy], 11.07.1921, leg. I. L. Raikova, rev. A. Nowak (TASH).

4. Gissar (Tajikistan?), 1933, leg. S. Kudriashev, rev. A. Nowak (TASH)

5. Koped-dag, Germab river (Turkmenistan) [Kopet-dag, in aquis frigidiusculis rivi prope p. Germab fluentis], 22.07.1927, leg. Vvedensky, rev. A. Nowak (TASH).

A list of specimens belonging to P. pusillus L. s. stricto collected from the territory of Tajikistan

1. Leninabad district, Farkhad reservoir [Leninabadskaya obl., Farkhadskoe vodokhronienie], 22.08.1947, leg. Kazantsev, rev. M. Nobis (TAD 1388).

2. Syrdar'ya river valley, in a lake [Bassein reki Syrdar'ya, v ozere], 23.05.1965, leg. Yu. Soekov, T. Duskabilov, rev. M. Nobis (TAD 129254).

3. Khovaling district, between Obi-Mazar and Shurab river [Khovalingskii raion, mezhdureche r. Obi-Mazar i Shurab, gornoe ozero po doroge ot Baldzhuana $\mathrm{v}$ Khovaling], 27.07.1960, leg. M. S. Lazareva, P. F. Kochkareva, rev. M. Nobis (TAD 151013).

4. Gissar valley, in gutter in Gissar village [Gissarskaya dolina, v aryke v pos. Gissar], 03.07.1912, leg. Grigorev, rev. M. Nobis (TAD 1930).

5. Regar village, in gutter [Regar, v aryke], 07.1934, leg. Chernov, Silanteva, rev. M. Nobis (TAD 77894, 1389).

6. Varzob river, $2 \mathrm{~km} \mathrm{~S}$ of Dushanbe [Reka Varzob, $2 \mathrm{~km}$ na Yug ot Stalinabada], 19.07.1912, leg. Grigorev, rev. M. Nobis (TAD 1391).

Distribution of both species in the territory of Tajikistan are presented in Figure 1.

\section{DISCUSSION}

Potamogeton berchtoldii and P. pusillus are placed among $P$. pusillus agg. Plasticity of the taxa included in this aggregation caused different taxonomical concepts introduced to literature. Complex was differently divided: in-

TABLE 1. A comparison of selected diagnostic features of $P$. pusillus and P. berchtoldii (based on Preston 1995, Wiegleb and Kaplan 1998, Zalewska-Gałosz 2008 and own observations).

\begin{tabular}{lll}
\hline Character & P.pusillus & P. berchtoldii \\
\hline stipules & connate, tubular & convolute, open \\
position of turions & axillary & terminal on main shoot and branches \\
lacunae along the midrib & absent or one row present & present in two or more rows \\
marginal vein & present & absent \\
nodal glands & present or absent & present, well developed \\
egzocarp & olive green, smooth & dark green, slightly rugose \\
endocarp & with central depression & without central depression \\
\hline
\end{tabular}



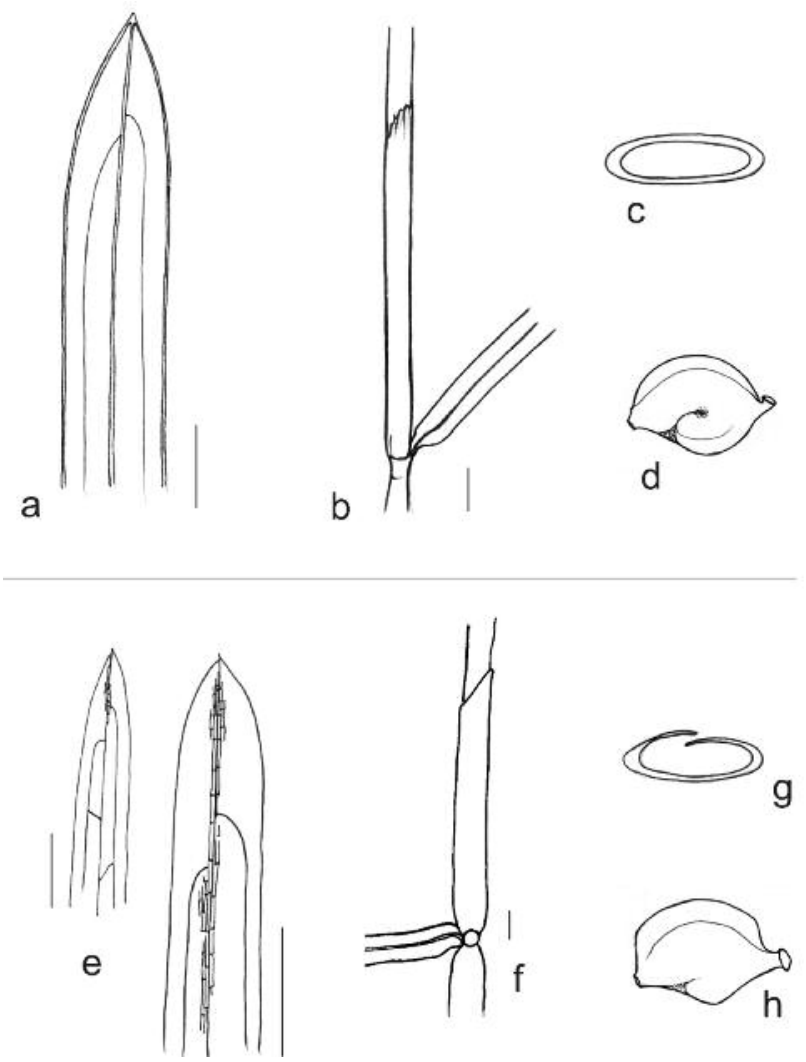

Fig. 2. Selected morphological features of Potamogeton pusillus (a-d) and $P$. berchtoldii (e-h): a, e - leaf apex; b, f - leaf base with stipules; c, g - section of stipule (just above the node); $\mathrm{d}, \mathrm{h}-$ sketch of fruit. Scale bar $1 \mathrm{~mm}$.

to several species (Ascherson and Graebner 1897), into two species (Hagstrom 1901; Fischer 1907; Fernald 1932) or treated as one, variable species $-P$. pusillus, with lower taxa distinguished (Graebner 1907). Nowadays, the existence of two species: $P$. pusillus and $P$. berchtoldii is widely accepted in Eurasia (Dandy 1980; Casper and Krausch 1980; Preston 1995; Kaplan and Štěpánek 2003). In North America these two taxa are also recognised, however recently in a range of subspecies (Haynes and Hellquist 2000).

The main differences between both species lay in stipules structure and position of turions. Stipules are open and convolute in $P$. berchtoldii but close and tubular in $P$. pusillus. Turions of $P$. berchtoldii are terminal on main shoots and branches while these of $P$. pusillus are usually sessile and axillary. Both species also can be distinguished using the colour and shape of fruits and some others distinctive characters, summarised in Table 1, and illustrated in Figure 2. Another, morphologically similar species, especially to the robust form of $P$. berchtoldii is $P$. friesii. However, like $P$. pusillus, young stipules of this species are closed and tubular. There are also a few additional characters, like strong marginal veins, fibrous stipules and different shape of turions which markedly differ $P$. friesii from $P$. berchtoldii.

Different taxonomical conceptions and complicated nomenclature created for taxa belonging to $P$. pusillus agg. impede proper definition of distribution ranges of both species. In general, however, $P$. pusillus and $P$. berchtoldii are rather common species and widely distributed. In Europe $P$. berchtoldii is absent only in outskirt islands of the continent like Azores, Balearics, Crete, Svalbard and also Spain,
Portugal and Sweden (Dandy 1980). In Asian records of $P$. berchtoldii are very scrappy. The species was noted e.g. from the territory of Russia, Bhutan, China, Japan, SE and SW Asia (Kipriyanova 2007; http://flora.huh.harvard.edu/ china/mss/volume23/Potamogetonaceae-AGH_reviewing.htm). It is possible that $P$. berchtoldii occurs more frequently in Tajikistan and adjacent countries than we provided but it seems to be far more rare than $P$. pusillus in that area.

\section{ACKNOWLEDGEMENTS}

We are grateful to the Curator of DUSH and TASH for making available the study collection. The research was supported by the Ministry of Science and Higher Education (grant no. N N304 377838).

\section{LITERATURE CITED}

ASCHERSON P., GRAEBNER P. 1897. Synopsis der mitteleuropäischen Flora. Vol. 1. Leipzig.

CASPER S.J., KRAUSCH H.-D. 1980. Pteridophyta und Anthophyta. 1. Teil: Lycopodiaceae bis Orchidaceae. In: Ettl H., Greloff J., Heynig H. (eds), Süßwasserflora von Mitteleuropa 23, pp. 403.

DANDY J.E. 1980. Potamogetonaceae. In: Tutin T.G., Heywood W.H., Burges N.A., Moore D.M., Valentine D.H., Walters S.M., Webb D.A. (eds), Flora Europaea. 5. Alismataceae to Orchidaceae (Monocotyledones). Cambridge University Press, Cambridge, p. 7-11.

FERNALD M.L. 1932. The linear-leaved North American species of Potamogeton, section Axillares. Mem. Amer. Acad. Arts Sci. 17: 1-183.

FISCHER G. 1907. Die bayerischen Potamogetonen und Zannichellien. Ber. Bayer. Bot. Ges. 11: 20-162.

GRAEBNER P. 1907. 4. Potamogeton (Tourn.) L. In: Engler A. (ed.), Das Pflanzenreich, Regni vegetabilis conspectus 31(VI.11), Berlin pp. 39-142, 161-162.

HAGRSTRÖM O. 1901. 1. Potamogeton Tourn. Nate. In: Neuman L.M. (ed.), Sveriges Flora. Lund, pp. 790-803.

HAYNES R.R., HELLQUIST C.B. 2000. Potamogeton. In: Flora of North America Editorial Committee (ed.), Flora of North America North of Mexico. New York, Oxford, 22: 47-74.

HOLMGREN P.K., HOLMGREN N.H., BARNETT L.C. 1990. Index Herbariorum Part I: The Herbaria of the World. New York Botanical Garden, Bronx, New York.

IKONNIKOV S.S. 1963. Opredelitel' rastenii Pamira [A key to identification of plants of Pamir]. Trudy Bot Inst Akad Nauk Tadziksk SSR 20: 1-281. (in Russian)

IKONNIKOV S.S. 1979. Opredielitel vysšich rastenij Badachschana [Definitotorium Plantarum Vascularium Badachschaniae]. Leningrad, Nauka, pp. 1-400. (in Russian)

KAPLAN Z. 2008. A taxonomic revision of Stuckenia (Potamogetonaceae) in Asia, with notes on the diversity and variation of the genus on a worldwide scale. Folia Geobot. 43: 159-234.

KAPLAN Z., ŠTĚPÁNEK J. 2003. Genetic variation within and between populations of Potamogeton pusillus agg. Plant Syst. Evol. 239: 95-112.

KIPRIYANOVA L.M. 2007. The Potamogeton species (Potamogetonaceae) and their ekology in forest-steppe and steppe lakes of the Novosibirsk region (West Siberia). Bot. Zhurn. 92(11): 1706-1716 (in Russian with English summary).

NOBIS M., NOWAK A. 2008. Contribution to taxonomy and distribution of species of the genus Stuckenia Börner (Potamogetonaceae) in the territory of Tajikistan (Middle Asia). In: Nowak A., Nobis M., Kusza G. (eds), Some aspects of nature 
conservation and environmental protection in Poland and Tajikistan. BIOS Ass., Opole, pp. 7-17. (in Russian with English summary)

PRESTON C.D. 1995. Pondweeds of Great Britain and Ireland. Botanical Society of the British Isles, B. S. B. I. Handbook 8, London.

SIDORENKO G.T. 1957. Potamogetonaceae Dumort. In: Ovczinnikow P.N. (ed.), Flora Tadzikskiej SSR. 1: 91-100. Wyd. Akad. Nauk SSSR, Moskwa-Leningrad.

VVEDENSKII A.I. 1968. Potamogeton L. - Rdest. Shalang (kaz.) - In: Kovalevskaja S.S. (ed.), 1, p. 39-42. Editio Acade- miae scientiarum Opredelitel' rastienii sredniei Azii (Conspectus florae Asiae Mediae) UzSSR, Taschkent.

WIEGLEB G., KAPLAN Z. 1998. An Account of the Species of Potamogeton L. (Potamogetonaceae). Folia Geobot. 33: 241-316.

ZAKIROV K.Z. 1961. Flora i rastitelnost basseina reki Zeravshan. 2, konspekt flory. Izdat. Akad. Nauk Uzbek. SSR. Tashkent, pp. 1-446.

ZALEWSKA-GAŁOSZ J. 2008. Rodzaj Potamogeton L. w Polsce - taksonomia i rozmieszczenie. Institute of Botany of the Jagiellonian University, Kraków, pp. 1-218. (in Polish with English summary) 